\title{
PULMONARY AND INTRACRANIAL RADIOGRAPHIC PRESENTATIONS OF LANGERHANS CELL HISTIOCYTOSIS
}

\author{
D. Mohammed*, S.B. Patel \\ SAINT JAMES SCHOOL OF MEDICINE, PARK RIDGE, IL, USA
}

Background. Langerhans Cell Histiocytosis is a rare disease that affects 1 to 2 adults per million worldwide and often consists of systemic manifestations including pulmonary, intracranial and osteolytic lesions and endocrinologic abnormalities such as Diabetes Insipidus.

Objective. The objective of this case report was to expand the medical literature of this rare disease.

Methods. A case report of a 51-year-old female patient presenting with systemic symptoms as a result of Langerhans Cell Histiocytosis is presented.

Results. A 51-year-old female presented with epistaxis, fatigue, polydipsia, polyuria, headaches and dyspnea. After initial $x$-rays showed multiple lung and liver nodules and the patient suffered subsequently from a unilateral pneumothorax, an open lung biopsy was recommended. On a pathological basis, the patient was diagnosed with Langerhans Cell Histiocytosis. This report focuses on the radiological presentations of the manifestations of Langerhans Cell Histiocytosis, particularly the presentations in the lung and intracranial regions.

Conclusions. Langerhans Cell Histiocytosis is an incredibly rare disease that presents systemically. Recognizing and differentiating radiographic presentation of these patients is important to determine the need for confirmation by biopsy and early chemotherapeutic intervention.

KEY WORDS: Langerhans Cell Histiocytosis; FDG-PET (positron emission with ${ }^{18} \mathrm{~F}-2$-deoxy-D-glucose (FDG); MRI (magnetic resonance imaging); X-ray.

\section{Introduction}

Langerhans Cell Histiocytosis is a rare disorder that affects approximately 1 to 2 adult patients per million worldwide [1]. Langerhans Cell Histiocytosis is the accepted terminology as past references of diffuse reticuloendotheliosis, Histiocytosis X, Hand-SchullerChristian disease and Letterer-Siwe disease are no longer used to refer to this pathology. The Birbeck granule is a characteristic feature of the Langerhans cell, which has several origins including monocytes, langerin positive dendritic cells, monocytes and langerin positive dendritic cells found in the lymphoid tissues [2]. These cells go through an induction process where they resemble the Langerhans cell phenotype [3]. Evidence for the neoplastic argument lays in the MAP2K1 and BRAF mutations in the MAPK pathway [4]. It is a group of disorders of idiopathic pathology although there has been much medical debate as to whether this pathology is neoplastic in nature or inflammatory. The pulmonary form of Langerhans Cell Histiocytosis is prevalent in approximately

*Corresponding Author: Denelle Mohammed, Saint James School of Medicine, 1480 Renaissance Drive, Suite 300, Park Ridge, IL 60068, USA.

e-mail:dmohammed@mail.sjsm.org
$10 \%$ of cases. In addition, pulmonary Langerhans Cell Histiocytosis expresses greater levels of CD207, S100 and CD1 a than other pulmonary diseases [5]. The most common variants of the pulmonary Langerhans Cell Histiocytosis include BRAF V600E and MAPK2K1 [5].

Objective. This case report details clinical evidence and radiographic findings of both the common intracranial and rarer pulmonary form of Langerhans Cell Histiocytosis and is an important work for recognizing presentations of the disease.

\section{Case Report}

A 51-year-old Native American female presented to the emergency department with a three-month history of severe headaches, unresolving epistaxis, weakness, mood swings, lower back pain, fatigue, dyspnea, polyuria, polyphagia and polydipsia. The patient's past medical history was positive for depression, nausea, vitiligo and hypothyroidism. She used Synthroid, Folic Acid, Bupropion and Metoclopramide with allergies to Metformin. Family history was positive for hypothyroidism, hypertension, diabetes, congestive heart failure, COPD and coronary artery disease. Surgical history was positive for a hysterectomy, double 
ovarian cystectomy, tonsillectomy and two C-sections. The patient's social history was positive for 25 pack years of tobacco smoking and social alcohol consumption. Physical examination revealed a pulse rate of 88 beats per minute, respiration was 18 breaths per minute, temperature was 37.5 degrees Celsius and blood pressure was $113 / 75 \mathrm{mmHg}$.

The decision was made to admit her to the hospital and complete testing secondary to some of the symptoms she was experiencing. $X$-rays were completed for dyspnea and lower back pain. The chest X-ray visualised multiple liver and lung nodules and MRI of both areas was recommended. The lung nodules were then biopsied endoscopically. Approximately two days after the lung nodule biopsy, the patient suffered a pneumothorax and a needle aspiration was performed. Upon stabilization and subsequent examination by the pulmonologist, an open lung biopsywas recommended to be sent for pathological review to a tertiary care centre. The pathological result showed CD1a, CD207 and BRAF V600E positive tissue. She was diagnosed with Langerhans Cell Histiocytosis and Diabetes Insipidus secondary to the primary diagnosis. An MRI of the brain both with and without contrast was performed where $\mathrm{T} 1$ isointense and $\mathrm{T} 2$ hyperintense signal areas in the hypothalamus and pituitary stalk were visualized. A $4.5 \mathrm{~mm} \times 4.5 \mathrm{~mm} \times 4.5 \mathrm{~mm}$ mass was found in the hypothalamus with an extension into the pituitary stalk. A T2 weighted image showed hyperintensity in the pons area and a thickened and enhanced pituitary stalk. A PET scan was done where diffuse and patchy hypermetabolic activity was found in the liver and spleen consistent with the pathologically confirmed diagnosis of Langerhans Cell Histiocytosis. An MRI of the abdomen showed an intense T2 signal in the portal triads. Centrilobular pulmonary nodules and hypermetabolic activity with lytic lesions in the sacrum and pelvis were found consistent with the diagnosis of Langerhans Cell Histiocytosis confirmed by open lung biopsy. There was the presence of $4 \mathrm{~mm}$ stellate nodules, both reticular and nodular opacities and honeycombing at the periphery of the lungs.

\section{Discussion}

The hallmarks of Langerhans Cell Histiocytosis are well known. These include lytic bone lesions in particular, which is the most common manifestation [1]. The jaw, vertebra, ribs, digits and skull are commonly involved. There can also be a papular and erythematous rash in the abdominal and groin area that can resemble a candida infection, found particularly in pediatric patients [1]. Oral manifestations of this pathology include ulcers of the soft mucosa, gingivitis and oral cavity masses [6]. Additional symptoms include lymphadenopathy, cystic hepatic lesions, splenomegaly and sclerosing cholangitis $[7,8]$.

Manifestations of the central nervous system include Diabetes Insipidus secondary to infiltration of the neurohypophysis, paraventricular or supraoptic nuclei as well as neurodegenerative issues affecting cognition and ataxia $[9,10]$. Diabetes Insipidus is the most common endocrinological presentation of Langerhans Cell Histiocytosis found in up to half of all cases [11]. This is closely followed by the deficiency of growth hormone [11]. The pituitary seems to be affected in a multitude of ways including vasopressin antibodies or invasion by histiocytes [10]. Diabetes Insipidus can occur months and even years before a formal diagnosis of Langerhans Cell Histiocytosis is given, similar to this patient's case presentation.

The intracranial radiographic changes are important to note in Langerhans Cell Histiocytosis as symptoms such as Diabetes Insipidus can occur for years before diagnosis. Hence, the onus is on the physician to determine the need for further clinical testing based on the radiographic presentation of this disease and implement swift chemotherapeutic interventions. Other cranial radiographic changes to consider include an empty sella, hypertrophied and atrophied, asymmetrical and hyperintense enhancement of the anterior pituitary [12]. The posterior pituitary can show T1W1 hyperintensity while the hypothalamus can show enhancement and lesions [12]. In this particular patient, T2 hyperintense signal areas and T1 isointense areas were seen in the hypothalamus in particular (Fig. 2). These hyperintensities also extended into the pituitary stalk and were consistent with the patient's diagnosis of Langerhans Cell Histiocytosis (Fig. 2). Other radiographic changes in the posterior pituitary in particular, include thickening of the pituitary stalk and also enhancement of that area with an absent T1W1 shortening visible [13]. Studies have shown that manifestations of Langerhans Cell Histiocytosis in the brain tend to occur in those areas without a blood brain barrier such as choroid plexuses, the pineal gland, meninges and circumventricular organs [14]. 


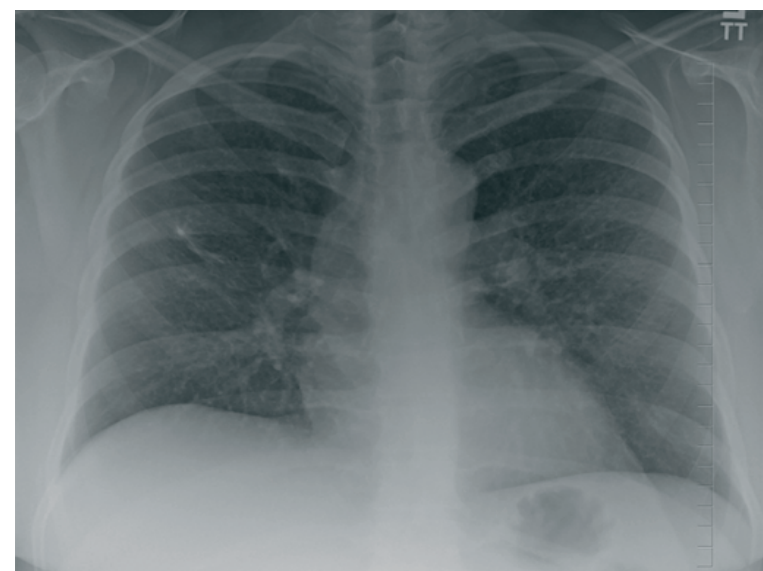

Fig. 1. Chest X-ray exhibiting centrilobular pulmonary nodules and pulmonary cysts with prominence in the bilateral upper lobes and reticular and nodular opacities consistent with Langerhans Cell Histiocytosis.

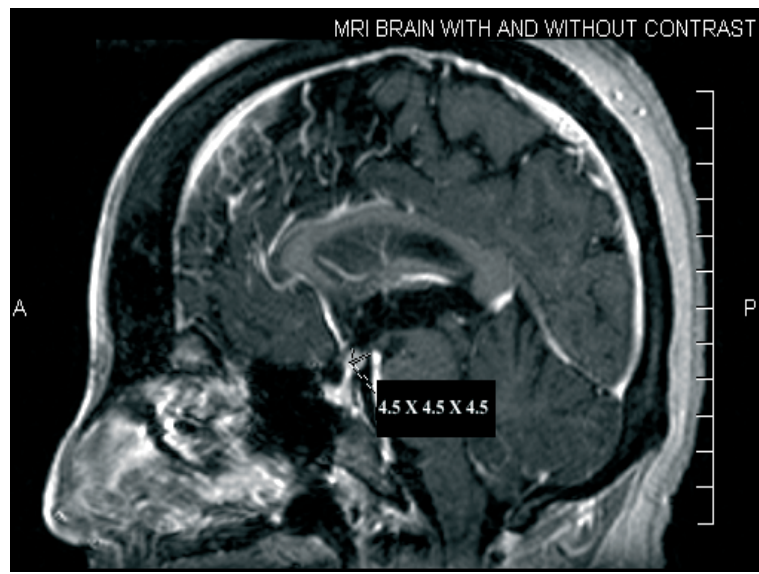

Fig. 2. A $4.5 \mathrm{~mm} \times 4.5 \mathrm{~mm} \times 4.5 \mathrm{~mm}$ enhancing hypothalamic mass with extension into the pituitary stalk consistent with Langerhans Cell Histiocytosis.

Neuroendocrine cells of the hypothalamus can project outside of the brain and hence can fall outside the realm of the blood brain barrier even though the actual hypothalamus is protected by one [14].

This case report is important since pulmonary Langerhans Cell Histiocytosis is uncommon and expanding the medical literature on this topic is important for radiologists to determine a possible differential for seemingly common features seen in other diseases such as honeycombing, reticular and nodular opacities. Lung involvement such as this patient's recurrent spontaneous pneumothorax and lung nodules are common in those with Langerhans Cell Histiocytosis [14]. Centrilobular pulmonary nodules with pulmonary cysts as seen in this patient's chest X-rays are radiographic findings that are consistent with an already pathologically diagnosed Langerhans Cell Histiocytosis (Fig. 1). Pulmonary involvement of Langerhans Cell Histiocytosis is a differential when features such as recurrent pneumothorax along with Diabetes Insipidus and bone pain co-occur [15]. Features specific to pulmonary Langerhans Cell Histiocytosis include nodular and reticular opacities, cysts in the upper lung zone along with honeycombing, normal lung volume, no involvement of the costophrenic angle and poorly defined or stellate nodules that may be up to $10 \mathrm{~mm}$ in size [16]. Stellate nodules, honeycombing and nodular and reticular opacities were also see in this patient upon histological examination. High resolution CT of the chest can also show interstitial thickening, thin-walled cysts and a general progression from non-cavitating nodules to cavitating nodules and subsequently cystic lesions [17]. Further radiologic presentation of Langerhans Cell Histiocytosis in FDG-PET form is seen by increased uptake in the lungs and nodular radiographic patterns [18].

\section{Conclusions}

This case report is important for understanding the simple radiographic presentations of an already rare disease. In conclusion, Langerhans Cell Histiocytosis is an uncommon disease with wide presentations in various organ systems. Radiographic recognition of this pathology can be beneficial to provide further testing and induction of a swift and proper therapeutic regimen.

\section{Conflict of interest}

The authors declare no conflict of interest. 


\title{
ЛЕГЕНЕВІ ТА ІНТРАКРАНІАЛЬНІ РАДІОГРАФІЧНІ ОЗНАКИ ГІСТІОЦИТОЗУ 3 КЛІТИН ЛАНГЕРГАНСА
}

\author{
D. Mohammed, S.B. Patel \\ SAINT JAMES SCHOOL OF MEDICINE, PARK RIDGE, IL, USA
}

\begin{abstract}
Вступ. Гістіоцитоз з клітин Лангерганса - рідкісне захворювання, що уражає 1-2 дорослих на мільйон, і часто має системний характер, включаючи остеолітичні прояви та нецукровий діабет серед багатьох інших клінічних симптомів.

Мета. Ознайомити читачів та привернути їх увагу до цього рідкісного захворювання

Методи. Описано та проаналізовано клінічний випадок гістіоцитозу з клітин Лангерганса з системними проявами.

Результати. 51-однорічна жінка поступила зі скаргами на носові кровотечі, постійну втому, спрагу, полідипсію та поліурію, головний біль, задишку. При першому рентгенологічному обстеженні виявлено численні вузлики улегенях та печінці, а згодом у пачієнтки розвинувся однобічний пневмоторакс. Після цього було рекомендовано провести біопсію легень. За результатами морфологічного обстеження встановлено діагноз гістіоцитозу з клітин Лангерганса. Описаний нами клінічний випадок фокусує увагу на проявах хвороби, які виявляються при променевих методах обстеження, особливо легень та голови (інтракраніальних ділянок).
\end{abstract}

Висновки. Гістіоцитоз з клітин Лангерганса уражає усі органи та системи організму. Типовими проявами єураження кісток, розвиток нецукрового діабету внаслідокураження гіпоталамо-гіпофізарної області, та наявність вузликів у легенях. Зміни, які виявляються променевими методами обстеження, надзвичайно важливі для встановлення потребиу проведенні біопсії та призначення хіміотерапевтичного лікування.

КЛЮЧОВІ СЛОВА: Гістіоцитоз з клітин Лангерганса; позитронно-емісійна томографія (ПЕТ)

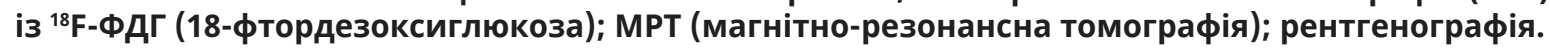

\section{Information about the author}

Denelle Mohammed - Department of Medicine, Saint James School of Medicine, 1480 Renaissance Drive, Suite 300, Park Ridge, IL 60068, USA.

ORCID 0000-0002-1639-2008, e-mail: dmohammed@mail.sjsm.org

Samarth B. Patel - Department of Medicine, Saint James School of Medicine, 1480 Renaissance Drive, Suite 300, Park Ridge, IL 60068, USA.

ORCID 0000-0003-0633-6376, e-mail: spatel2@mail.sjsm.org

\section{References}

1. Baumgartner I, von Hochstetter A, Baumert B, Luetolf U, Follath F. Langerhans'-cell histiocytosis in adults. Med Pediatr Oncol. 1997;28(1):9-14.

d o i : $10.1002 /($ S I C I ) 1096 911X(199701)28:1<9::AID-MPO3>3.0.CO;2-P

2. Merad M, Ginhoux F, Collin M. Origin, homeostasis and function of Langerhans cells and other langerin-expressing dendritic cells. Nat Rev Immunol. 2008;8(12):935-47.

doi: $10.1038 /$ nri2455

3. Egeler RM, van Halteren AG, Hogendoorn PC, Laman JD, Leenen PJ. Langerhans cell histiocytosis: fascinating dynamics of the dendritic cell-macrophage lineage. Immunol Rev. 2010;234(1):213-32.

doi: 10.1111/j.0105-2896.2009.00883.x

4. Brown NA, Furtado LV, Betz BL, Kiel MJ, Weigelin HC, Lim MS, Elenitoba-Johnson KS. High prevalence of somatic MAP2K1 mutations in BRAF V600E-negative Langerhans cell histiocytosis. Blood. 2014;124(10):1655-8.

doi: 10.1182/blood-2014-05-577361
5. Roden AC, Yi ES. Pulmonary Langerhans cell histiocytosis: an update from the pathologists' perspective. Archives of pathology \& laboratory medicine. 2016;140(3):230-40.

doi: 10.5858/arpa.2015-0246-RA

6. Annibali S, Cristalli MP, Solidani M, Ciavarella D, La Monaca G, Suriano MM, Lo Muzio L, Lo Russo L. Langerhans cell histiocytosis: oral/periodontal involvement in adult patients. Oral diseases. 2009 Nov;15(8):596-601.

doi: 10.1111/j.1601-0825.2009.01601.x

7. Braier JL, Rosso D, Latella A, Chantada G, Ozuna B, Ripoli M, Scopinaro M. Importance of multilineage hematologic involvement and hypoalbuminemia at diagnosis in patients with "risk-organ" multi-system Langerhans cell histiocytosis. Journal of pediatric hematology/oncology. 2010 May 1;32(4):e122-5.

doi: 10.1097/MPH.0b013e3181d7acc5 
8. Grois N, Fahrner B, Arceci RJ, Henter JI, McClain K, Lassmann H, Nanduri V, Prosch H, Prayer D. Central nervous system disease in Langerhans cell histiocytosis. The Journal of pediatrics. 2010 Jun 1;156(6):873-81.

doi: 10.1016/j.jpeds.2010.03.001

9. Kaltsas GA, Powles TB, Evanson J, Plowman PN, Drinkwater JE, Jenkins PJ, Monson JP, Besser GM, Grossman AB. Hypothalamo-pituitary abnormalities in adult patients with langerhans cell histiocytosis: clinical, endocrinological, and radiological features and response to treatment. The Journal of Clinical Endocrinology \& Metabolism. 2000 Apr 1;85(4):1370-6. doi: $10.1210 /$ jcem.85.4.6501

10. Mittheisz E, Seidl R, Prayer D, Waldenmair M, Neophytou B, Pötschger U, Minkov M, Steiner M, Prosch H, Wnorowski M, Gadner H. Central nervous system-related permanent consequences in patients with Langerhans cell histiocytosis. Pediatric blood \& cancer. 2007 Jan;48(1):50-6.

doi: 10.1002/pbc.20760

11. Maghnie M, Genovese E, Bernasconi S, Binda S, Arico M. Persistent high MR signal of the posterior pituitary gland in central diabetes insipidus. AJNR Am J Neuroradiol. 1997;18:1749-52. full.pdf http://www.ajnr.org/content/ajnr/18/9/1749.

12. Prayer D, Grois N, Prosch H, Gadner H, and Barkovich AJ. MR Imaging Presentation of Intracranial Disease Associated with Langerhans Cell Histiocytosis. AJNR Am J Neuroradiol. 2004;25:880-91. http://www.ajnr.org/content/25/5/880.long
13. Ganong WF. Circumventricular organs: definition and role in the regulation of endocrine and autonomic function. Clin Exp Pharmacol Physiol. 2000;27:422-7.

doi: 10.1046/j.1440-1681.2000.03259.x

14. Odame I, Li P, Lau L, Doda W, Noseworthy M, Babyn P, Weitzman S. Pulmonary Langerhans cell histiocytosis: a variable disease in childhood. Pediatric blood \& cancer. 2006 Dec 1;47(7):889-93.

doi: 10.1002/pbc.20676

15. Samanci NS, Ayer M. Multisystem involvement of Langerhans cell histiocytosis in an adult. The Indian journal of medical research. 2019;149:78.

doi: 10.4103/ijmr.IJMR_1726_17

16. Kulwiec EL, Lynch DA, Aguayo SM, Schwarz MI, King Jr T. Imaging of pulmonary histiocytosis $X$. Radiographics. 1992;12:515-26.

doi: 10.1148/radiographics. 12.3.1609142

17. Castoldi MC, Verrioli A, De Juli E, Vanzulli A. Pulmonary Langerhans cell histiocytosis: the many faces of presentation at initial CT scan. Insights into imaging. 2014;5:483-92.

doi: 10.1007/s13244-014-0338-0

18. Krajicek BJ, Ryu JH, Hartman TE, Lowe VJ, Vassallo R. Abnormal fluorodeoxyglucose PET in pulmonary Langerhans cell histiocytosis. Chest. 2009;135:1542-9.

doi: 10.1378/chest.08-1899

Received 30 May 2019; revised 11 June 2019; accepted 18 June 2019.

This is an open access article distributed under the Creative Commons Attribution License, which permits unrestricted use, distribution, and reproduction in any medium, provided the original work is properly cited. 